\title{
Merging of Game Principles and Learning Strategy using Apps for Science Subjects to Enhance Student Interest and Understanding
}

\author{
Nazirah Mat Sin ${ }^{a^{*}}$, Othman Taliba, Tengku Putri Norishaha \\ ${ }^{a}$ Faculty of Educational Studies, University of Putra Malaysia, Serdang, Selangor \\ *Corresponding author: nazirah.matsin@mmu.edu.my
}

Article history

Received :11 December 2012

Received in revised form :

30 August 2013

Accepted : 15 September 2013

\begin{abstract}
The popularity of digital games is undeniable. There are numerous studies on digital games based learning (DGBL) which demonstrate the increased interest in digital games among students. Conversely, there has been a significant decline of interest in learning science. DGBL merges principles and strategies from the game and education fields. It is believed the combination of these two fields would enhance interest in learning science as well as assist students to understand highly conceptual subjects such as Chemistry. However, researchers face challenges to integrate principles of games into educational theories which are often too broad to be implemented in DGBL development. As such, this conceptual paper tries to discuss the potential of merging game principles and learning strategies in DGBL for teaching science concepts.

Keywords: Digital game based learning; conceptual framework; game principle; learning strategy

Abstrak

Kajian literatur menunjukkan terdapat peningkatan terhadap minat bermain permainan digital di kalangan pelajar. Pada masa yang sama, kajian literatur turut menunjukkan kemerosotan minat pelajar terhadap pembelajaran Sains. Pembelajaran berasaskan permainan digital (Digital game based learning) adalah hasil gabungan prinsip dan strategi antara domain permainan dan pendidikan. Gabungan dua domain ini dipercayai berupaya meningkatkan minat pelajar terhadap bidang Sains dan membantu meningkatkan pemahaman pelajar dalam mempelajari subjek Sains yang kompleks. Walaupun begitu, cabaran dihadapi apabila mengaplikasikan prinsip permainan di dalam teori pendidikan disebabkan ciri-ciri prinsip yang terlalu umum. Jesteru itu, artikel konseptual ini membincangkan potensi penggabungan prinsip permainan digital dan strategi pembelajaran dalam pembelajaran berasaskan permainan digital (DGBL) dalam mempelajari konsep Sains.
\end{abstract}

C) 2013 Penerbit UTM Press. All rights reserved.

\subsection{INTRODUCTION}

Students' lack of interest in science subjects such as Chemistry, Physics and Biology is an on-going debatable issue since before we can remember. The issue is faced by both developed and developing countries. A report by Daiichi Sankyo (2011) mentioned that only $5 \%$ of students in United States of undergraduate levels pursue their studies in Science related programmes. Another report by STEMTech alliance (2009) reported that only $22 \%$ of students in Massachusetts, United States showed interests to further their studies in science related programmes. In England, students' interest toward Science subjects has declined when the students entered secondary schools (Barmby, Kind, \& Jones, 2008).

In Malaysia, decline of interest toward Science subjects is a continuous debatable issue. According to Zanaton, Lilia, and Kamisah (2006), students' interest toward science subjects was declining. 6 years later, students' interest toward science subjects continuously decreasing: Number of Science students in Malaysian secondary schools consisted of only $29 \%$. The numbers are far from
Malaysian ministry of education target that is to have $60 \%$ of science stream students (Ruhaiza, 2012). Issue lack of interest in Science subjects is undeniable. The issue is crucial as science has been considered as the driving force of economy development by many countries (Logan \& Skamp, 2007).2:1 (dendrimer:diamine) ratio. At low concentration, thin fibres were present (Figure 2a), which at higher concentration aggregate and assemble into thick fibre bundles (Figure 2b). The effect of molar concentration on the thermally reversible gel-sol phase transition $\left(T_{\mathrm{gel}}\right)$ was monitored using the tube inversion technique. ${ }^{11}$ The validity of this approach, and the reversibility of the phase transition, was checked with differential scanning calorimetry. As the molar concentration of the dual components

\subsection{COMPLEXITY OF SCIENCE SUBJECTS}

Many factors contribute to students' lack of interest in science subjects. However, this paper focuses only on complexity of science subjects that leads to students' lack of interest in science. 
Science subjects demand students' higher level of thinking: Students are expected to understand the underlying concept of each science subject using critical thinking (Yang, 2010). Consequently, this has caused difficulties among students to understand science subjects including the basic knowledge of science.

Besides that, significance of science subjects in students' routines live has been one of the major factors that contribute to students' lack of interest toward Science. Many students thought that it is impossible to relate science in daily life (Yang, 2010; Logan \& Skamp, 2007). On top of that, significance of science outside of classrooms plays main factor in determining students' interest toward science subjects in their higher education level. (Ahmad Nurulazam, Rohandi, \& Azman, 2010). Although previous studies indicated that students' interest toward science closely related to the students' ability to relate Science in their informal surrounding, the factor only viable during primary school level. However, when entering secondary school level, students' attitude and interest in science rely on the students' experiences of learning science in classroom environment (Barmby, Kind, \& Jones, 2008). This suggests that both inside and outside of school environment are important in learning science subjects.

Complexity of science subjects can be solved through appropriate use of Information communication technology (ICT) equipment. It is believed ICT usage could hinder students' decline of interest in science subject (Varley, Murphy, \& Veale, 2011; Logan \& Skamp, 2007). One of the solutions is through digital game integration in formal education setting.

\subsection{DIGITAL GAME}

Entertainment Software Association (2005) estimated that there are $35 \%$ of computer game players aged 18 and below. Almost one third of digital content purchased by consumers in year 2010 consisted of games and it generated billions dollars profit s. In Malaysia, both primary and secondary school students admitted that they play digital games. Among these respondents, $96 \%$ of male and $90 \%$ of female students had been reported play digital games inside and outside of school area (Rubijesmin, 2007). Students' interest toward games has attracted education professions to integrate game play in education setting. Although the notion of digital game integration in education seems interesting, execution of the idea is challenging. Game is produced solely for entertainment sake. While education is meant to teach, careful consideration should be made when merging these two domains.

\subsection{Difinition of Game and Digital Game Based Learning}

Game definition varies: There is no one standard definition of game could be found. According to Clark \& Mayer (2011), game is "an online environment that involves a competitive activity with a challenge to achieve a goal, a set of rules and constraints, and a specific context" (p.461). In a different study, Huang (2010) defined game as digital or non-digital environment where players compete to achieve goals of game by following the game's criteria. Rieber (2005) described that game involves human interaction with multimedia elements but the level of interaction is higher than normal multimedia courseware. The interaction is also based on specific rules and guidelines. As visualized in Figure 1, Prensky defined game as 'organized play' (2001, p.119). Although there is no one standard definition used to describe game, the similarities of game definitions could be identified. In this article, game is defined as an interaction of one or more than one player with multimedia components. The interaction is based on specific rules where a player has to follow in order to achieve goals of a game.

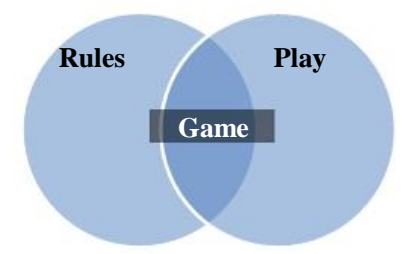

Figure 1 Rules and play characterize games (Flynt, 2006)

The term digital game based learning (DGBL) was first introduced by Prensky (2001). In general, digital game based learning is defined as the usage of electronic games for learning intention (Thang, Hanneghan, \& Rhalibi, 2009). In addition, DGBL that has been produced must be based on any educational content such as chemistry and mathematics. By end of the game playing session, students are expected to achieve specific learning objectives. Students' achievements can be assessed during the game play or by end of the game playing session (Huang, 2010).

Both game and digital game based learning have almost similar definitions. The differences of these two terms are the purpose: Game is developed solely for entertainment sake while digital game based learning is developed to educate new knowledge and skills to game players or students. In this paper, game and DGBL will be used interchangeably.

\subsection{Previous Studies in Digital Game Based Learning}

Studies related to DGBL is increasing: These studies involved various subjects include Physics, Mathematics, Geography, and Computer Science (Demirbilek \& Tamer 2010; Sadiq, 2010; Tüzün, Yılmaz-Soylu, Karakus, Inal \& Kızılkaya, 2009; Çankayaa, \& Karameteb 2009; Papastergiou, 2009; Kebritchi, 2008; Neimeyer, 2006).

Much studies in DGBL showed positive results in students' learning. Finding from digital game based learning studies in Mathematics reported that students' performance in the subject had increased. Besides that, students' motivation and interest toward Mathematics also showed positive outcomes (Demirbilek \& Tamer 2010; Çankayaa, \& Karameteb 2009; Neimeyer, 2006). In a different study, students' performance in Physics had increased when learning using digital game based learning approach (Sadiq, 2010). Study conducted in effectiveness of digital game based learning impact in computer science subject reported that DGBL had potential in helping students to learn conceptual knowledge such as learning concept of computer memory (Papastergiou, 2009). Papastergiou also explained that students were more motivated to learn computer science subject using DGBL approach. Based on positive results showed from the previous studies, it proves potential of digital game play in education. Although previous studies showed positive results in digital game based learning, thorough plan should be considered when designing digital game based learning product. According to Clark \& Mayer (2011), "Yes, simulation and game do teach, but the lesson learned is always not the intended one" (p. 16).

\subsection{Current Used of Apps in Education}

Game industry has continuously evolved especially with the rapid growth of handheld device such as smart phone, tablet and note book: Software applications known as apps refer to various types of software applications including game applications that are downloadable from internet into handheld device (Kinsey, 2011). 
Apple.com reported that 10 billion of apps have been downloaded from Apple App Store alone.

Although apps have been utilized by mobile owners, its usage, research and development in education context can be considered relatively new (Felicello, 2011). Previous studies related to apps in education reported that English language learning such as reading and learning vocabulary is the most studied and researched area (Felicello, 2011). Besides learning English language, study conducted in Mathematics app has been reported (Payne, 2007): The quantitative study reported that the mathematics app is effective for students in high poverty schools. Another study reported that app in Probability topic had increased students' engagement toward the topic and also at the same time increase students' self-learning ability (Atan, , 2010). In a study conducted by Hansel, Phimmavong, Phengsopha, Phompila, and Homduangpachan (2010), on teaching students about nature conservation, results showed $21 \%$ improvement during the posttest. A quasi-experimental study conducted in mobile game based learning in learning history of medieval Amsterdam showed that students are more enggaged and gained more knowledge than those who did not learn using the game based learning apps (Huizenga, Admiraal, Akkerman, \& Dam, 2009).

Researchers of the previous studies justified that apps were used as part of their research as apps act as an enabler to provide an ubiquitous and self-pace learning environment for students. Besides that, as most students are equipped with hand-held device, educational apps are seen as an appropriate approach to teach students using technology platform that students are already familiar with (Redd, 2011).

\subsection{CONCEPTUAL FRAMEWORK OF DIGITAL GAME BASED LEARNING}

Applying learning theories and strategies in developing any medium of learning instruction including game is necessary. Applications that are developed based on strong educational theories would increase the application potential in helping students to learn. However, the process of merging education theories and game principles is an issue that is yet to be solved: There is no standard procedure to combine these two areas (Prensky, 2001b). In this study, common game criteria, Clark \& Mayer (2011) Principle of game and Gagne nine events of instruction are merged as framework for the study.

\subsection{Common Game Criteria}

Game is usually developed based on a set of criteria. Most common game criteria consisted of play, culture, rule and goal. Play relates to players' involvement during game play that includes interaction and obstacles. While rules refer to game levels: Game levels usually indicate difficulty stages that player has to overcome in order to achieve the game goals. The last criterion is culture. Culture portrays each game context: It has the ability to affect players' emotion and believability during game play (Thang, Hanneghan, \& Rhalibi, 2009). In a different study, Mayer and Johnson (2010) added collective as the fourth common criteria. Collective denotes that any decision made during game play from previous level will affect player's state of current level. This implies cause and effect for every decision made during game play session. Most games are developed based on these criteria. The last important common criterion of game is goal: Goal refers to target that should be achieved by users when playing games such as collect most gold coins or to save princess. These criteria motivate game players to keep playing games (Prensky, 2001). As shown in
Figure 2, these common criteria will be used as a basis for the conceptual framework proposed in this paper.

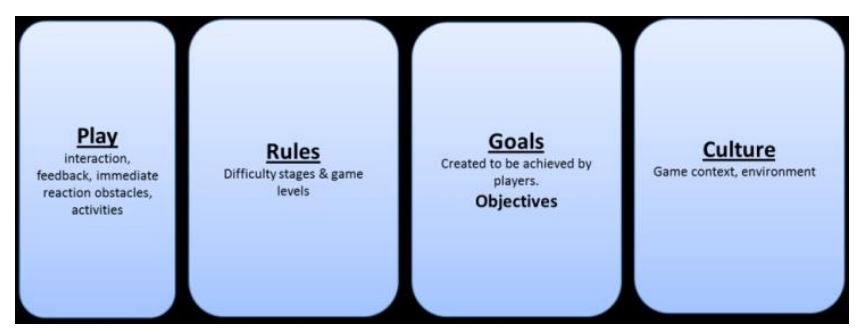

Figure 2 Common criteria of game implemented in the study

\subsection{Clark and Mayer Principle of Game}

Clark and Mayer Principle of Games (Clark \& Mayer, 2011) have been created for DGBL. According to Clark and Mayer, these principles have been developed based on empirical researches done by previous researchers. The principles are believed could optimize students' learning potential in digital game based learning environment.

Clark and Mayer (2011) listed six principles of games: “(1) Match game types to learning goals, (2) make learning essential to game progress, (3) build in proven instructional strategies, (4) build in guidance and structure, (5) manage complexity, (6) and make relevance salient" (p.381). The first principle suggests that learning goals or objectives should be the basis of any digital game based learning. Next principle recommends that students' learning during game play should be paralleled with learning goals of digital game based learning. The third principle recommends adoption of learning strategies that have been well research: Rather than reinvent the wheel, Clark and Mayer suggest game developers to adopt well known learning strategies into digital game based learning. One of the examples includes provide explanatory feedback that are relevant, sufficient and descriptive to game players. The fourth principle is built in guidance and structure. Unlike most authentic game that focuses solely on entertainment and self-exploration, digital game based learning should avoid selfdiscovery learning. Besides that, digital game based learning should be equipped with sufficient audio visual aids. Audio visual aids should be designed in concise and precise manner. This is to ensure knowledge would be imparted to students during game play session. The fifth principle is managing complexity. Managing complexity includes provide students with pre-game session to help students to get familiar with the digital game based learning. Besides pre-game session, digital game based learning should be developed from easy to most difficult level. On top of that, like any e-learning content, digital game based learning should be developed with appropriate pace. The pace depends on type of knowledge and target audience. The last principle is to ensure relevance of digital game based learning to students. Students should be made aware that the game play is not merely for entertainment sake but most importantly to learn new knowledge.

Although the game principles have been created as guidelines in digital game based learning instruction, the guidelines can be considered general. A step-by-step guidance for digital game based learning instruction is needed especially to novice digital game based learning creator. Therefore, Gagne's nine events of instructions have been selected to be merged with principle of simulation and games. Gagne's nine event of instructions have been selected as the learning strategies effectiveness have been empirically proven effective and it is well implemented in other digital game based learning research too. 


\subsection{Gagne Nine Events of Instruction}

Gagne's nine events of instructions reside under cognitive educational learning theories family. In cognitive perspective, students' ability to process information presented to them during game play would be the main focus of learning. There are two types of learning outcomes should be evaluated when using Gagne or any cognitive approaches: Knowledge and Skills. Under knowledge stage, students should be able to remember information presented to them during game play. Where else, a higher level of thinking is expected under skills: Students should be able to solve problem and make decision during game play activities (Wouters, Spek, \& Oostendorp, 2009).

Gagne's condition of learning theory implementation in digital game based learning could increase students' learning effectiveness (Becker, 2005). There are nine events of instruction suggested by Gagne when transferring knowledge to students. The nine instructions are (1) Gaining attention (2) Informing learner objective (3) Stimulating recall of prior learning (4) Presenting the stimulus (5) Providing learner guidance (6) Eliciting performance (7) Providing feedback (8) Assessing performance and (9) Enhancing retention and transfer.

Gagne's condition of learning theory has been well applied in multimedia educational applications and it is believed that digital game based learning development with Gagne's condition of learning approach would produce better learning result (Gunter, Kenny, \& Vick, 2006). The theory is suitable in digital game based learning approach in many subject areas including in science subjects (Teh, Wan Ismail, \& Toh, 2010). An example of game that used Gagne's condition of learning as one of the approach is Pokemon game to develop reading skills. The game had been reported able to develop pre-school students reading skills (Becker, 2007). In a different study, it had been found that high school students with average and below average academic level achieved higher results when learning through digital game based learning that had been developed based on sound learning theories include Gagne's condition of learning (Teh, Wan Ismail, \& Toh, 2010). Another digital game based learning that had been developed using Gagne's condition of learning was a game for civil engineering subject master level students (Ebner \& Holzinger, 2007): Researchers of the study found that students enjoyed learning during the game play. Results from the study also showed that students who experienced the digital game based learning approach produced at least similar results with students who only experienced conventional classroom teaching approach of the subject.

Gagne sequence of instruction has been developed to assist educators to structure their lessons that would produce effective learning and subsequently produce positive learning outcomes from students (Mountain, 2009a). Unlike conventional lesson that can adopt the instructions in sequential manner, the art of adopting and implementing Gagne in game varies. These steps can be merged and integrated (Becker, 2007). Digital content creation that is developed based Gagne Nine event of instruction would produce dynamic learning (Mountain, 2009b). Development of digital game based learning that integrates Gagne Nine Events of instruction is important to ensure the quality of the produced digital game based learning.

\subsection{MERGING OF GAMES AND INSTRUCTIONS DGBL}

There is no one standard practice to implement theories in digital game based learning. In this paper, all the theories are listed in Table 1: Elements reside in each theory are defined and understood by authors of the study as explained earlier in the same section of this article. Elements that have similar meaning and functions are grouped together.

In this paper a conceptual framework of DGBL is proposed by merging Clark and Mayer's game principles, Gagne nine events of instruction and common game criteria. The framework is proposed due to increase research interest in DGBL. At the same time, there is limited existing framework in DGBL especially in Science subjects. In this paper, the proposed framework is known as Conceptual Framework of Digital Game based Learning (DGBL). Figure 3 represents general concept of the conceptual framework. The proposed framework consists of five interrelated components. It is believes the integration of these components would facilitate learning, optimize learning and ensure students' achievement.

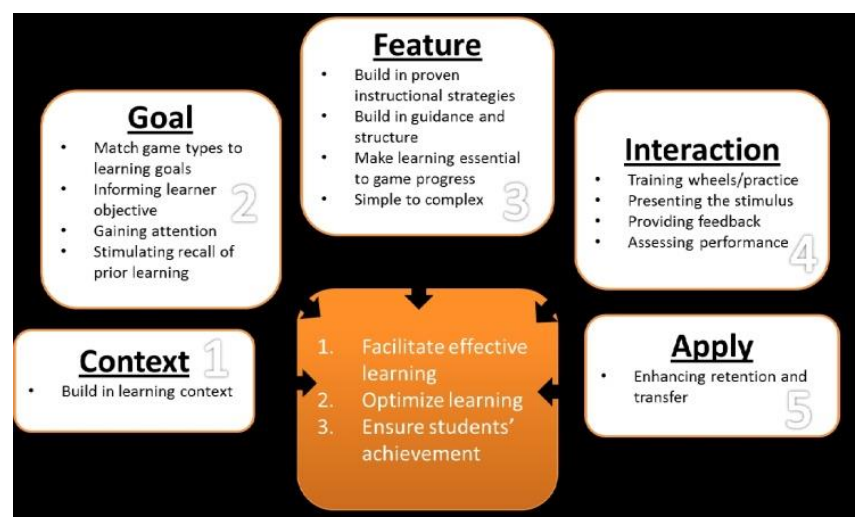

Figure 3 Conceptual framework of DGBL

\subsection{Context}

Context of game has similar definition and function with culture in game common criteria (Table 1). In the proposed DGBL framework, Context phrase has been used to replace Culture as the phrase provides an unambiguous definition. Based on Clark and Mayer's Game Principles, game context should be created with clarity and significance to target players. In other words, content of DGBL and target users should be appropriately determined when developing game instruction in DGBL. Content does not only refer to knowledge such as Chemistry but it also includes activity, feedbacks and interaction. All these should be developed in context with target users and content.

\subsection{Goal}

Goal shares similar meaning to learning objective in Gagne Nine Events of Instructions. Most digital games create goals for players to achieve: Examples of goal in games are to collect the most gold coins or to save a princess lock in tower. Similar to learning environment, all learning should start with learning objectives. Learning objectives refer to knowledge that is expected to be acquired by students at the end of learning session. Both goal and learning objective shares similar meaning that is target set for players and students to achieve. In Conceptual Framework of Digital Game based Learning (DGBL), goal refers to DGBL educational target that should be achieved by players during game play session.

Goal components comprise of (1) match game type to learning goal, (2) informing learner objective, (3) gaining attention (4) and stimulating recall of prior learning. In the proposed framework, match game type to learning goal refers to the act of identifying genre of game that suite learning objective and instruction. The second component is informing learning objective that means to 
make explicit the expectation that is expected toward students who play the DGBL. Unlike conventional learning, learning objective is informed by teacher in face-to-face mode, in DGBL learning objective is informed beginning of a game through trailer, storytelling or animation form. The next component is gain attention. Gain attention is important to capture students' interest to play the game. The last component is stimulating recall of prior learning. As some DGBL would require prerequisite knowledge from students, it is important to inform students' prior knowledge in the introduction stage.

Table 1 Common game criteria, Gagne's nine events of instruction and principle of simulation and game

\begin{tabular}{|c|c|c|}
\hline Common Game Criteria & Principle of Simulation and Games & Gagne's Nine Eevnts of Instructions \\
\hline \multirow{4}{*}{$\begin{array}{ll}1 . & \text { Goal } \\
2 . & \text { Play } \\
\text { 3. } & \text { rule } \\
\text { 4. } & \text { Culture }\end{array}$} & 1. Match game types to learning goals & 1. Gaining attention \\
\hline & 2. Make learning essential togame progress & 2. Informing learner obiective \\
\hline & 2. Mrake learning essentua togame progress & 2. mon \\
\hline & 3. Build in proven instructional strategies & 3. Stimulating recall of prior \\
\hline & 4. Build in guidance and structure & learning \\
\hline & 5. Manage complexity & 4. Presenting the stimulus \\
\hline & Make relevance salient & 5. Providing learner guidance \\
\hline & & 6. Eliciting performance \\
\hline & & 7. Providing feedback \\
\hline & & 8. Assessing performance \\
\hline & & 9.Enhancing retention and transfer. \\
\hline
\end{tabular}

\subsection{Feature}

Feature refers to other instructional components that should be included in DGBL. In the proposed framework Feature comprises of (1) build in proven instructional strategies, (2) build in guidance and structure; (3) make learning essential to game progress and (4) simple to complex. These components are based on Clark and Mayer's principle of games. The first attribute of Feature that is built in proven instructional strategies is development of game based on existing learning strategies such as explanatory feedback and self-explanation question. In authentic digital game, instructional strategies are not needed as the game is created solely for entertainment. But in DGBL, instructional strategy elements are in need to ensure learning does occur during game play. The second attribute of Feature is Built in guidance and structure: The attribute refers to assistance that should be integrated in DGBL. Clark and Mayer (2011) suggest guidance should comprise of visual, verbal explanation and avoidance of self-discovery learning. The third attribute is make learning essential to game progress. This attribute refers to ensuring knowledge that students gained are appropriate with the intended goal. The final attribute is simple to complex: Level of game difficulties should start from the easy stage.

\subsection{Interaction}

Interaction refers to interaction between player and game during game play session. This component also refers to game play session. In this stage, students gain knowledge while interacting with DGBL application. Interaction comprises of practice, presenting stimulus, feedback and assessing performance. All these attributes reflect interaction activities that occur during game play session. Practice refers to providing students with trial session before students play the real DGBL. This is to help students to get familiar with the game environment and features. The second attribute is presenting stimulus: This is actually the game play session or active participation in the game. The third attribute is feedback that refers to points gained or deducted whenever students make correct or wrong decision. The last attribute is assessing performance: This attribute refers to exam or test. In DGBL context, students' performance is assessed the whole game play session.

\subsection{Apply}

The last component of the proposed framework is Apply. It refers to application of new knowledge gained during learning to outside learning environment. In DGBL environment, Apply or enhancing retention and transfer happens when students or DGBL players are able to apply knowledge they have gained in current level into the next level. This act would increase students' retention toward the learned knowledge. At the same time it provides students with a meaningful learning when they are able to apply new knowledge in the next game level.

\subsection{CONCLUSION}

In all, this concept paper had aimed to describe issues and factors that lead to DGBL integration in education especially in science subjects. Most importantly this study had identified and discussed the potential of game common criteria, Clark and Mayer's Principle of Game and Gagne Nine Events in DGBL. A conceptual framework of DGBL has been proposed based on these theories. The proposed conceptual framework could be used to implement game based learning instruction. However, further studies are in need to prove the conceptual framework effectiveness. Future studies will be conducted to implement and investigated the proposed framework.

\section{Acknowledgement}

The authors would like to acknowledge MMU for partly funding this project under the mini fund grant of IP20120510020. 


\section{References}

Essential facts about the computer and video game industry. (2005, June 28). Retrieved 2011, from Entertainment Software Association: http://www.theesa.com/files/ 2005EssentialFacts.pdf

Entertainment Software Association. 2012. Retrieved May 22, 2012, from Industry Facts: http://www.theesa. com/facts/index.asp

Ahmad Nurulazam, M., Rohandi, \& Azman, J. 2010. Instructional Congruence to Improve Malaysian Students' Attitudes and Interests Toward Science in Low Performing Secondary Schools. European Journal of Social Sciences. 13(1).

Atan, M. S. 2010. A Study of Students' Perception of Mobile Learning in Probability Lessons. Multimedia University (Malaysia)). ProQuest Dissertations and Theses, Retrieved from http://search.proquest.com/docview/926195307? accountid=48462

Aydın, Y. C., \& Uzuntiryaki, E. 2009. Development and Psychometric Evaluation of the High School Chemistry Self-Efficacy Scale. Educational and Psychological Measurement.

Barmby, P., Kind, P., \& Jones, K. 2008. Examining Changing Attitudes in Secondary School Science. International Journal of Science Education. 30(8): 1075-1093.doi:10.1080/09500690701344966.

Becker, K. 2007. Pedagogy in Commercial Games. In D. Gibson, C. Aldrich, \& M. Prensky, Games and Simulations in Online Learning. Research And Development Frameworks Information Science Publishing. 21-49.

Çankaya, S., \& Karamete, A. 2009. The Effects of Educational Computer Games on Students' Attitudes Towards. Procedia Social and Behavioral Sciences. 1: 145-149.

Chong Liang, J., \& Chung Tsai, C. (2010, November 15). Relational Analysis of College Science-major Students' Epistemological Beliefs Toward Science and Conceptions of Learning Science. International Journal of Science Education. 32(17): 2273-2289.

Clark, R. C., \& Mayer, R. E. 2011. E-Learning and the Science of Instruction. San Fransisco: Pfeiffer.

Creswell, J. W. 2008. Educational Research: Planning, Conducting and Evaluating Quantitative and Qualitative Research. 3rd ed. New Jersey: Pearson Education

Duvarci, D. 2010. Activity-based Chemistry Teaching: A Case of Elements. 2506-2509.

Duvarci, D. 2010. Activity-based Chemistry Teaching: A Case of Elements and Compounds. Procedia Social and Behavioral Sciences. Elsevier Ltd. 2: 2506-2509.

Ebner, M., \& Holzinger, A. 2007. Successful Implementation of User-centered Game Based Learning in Higher Education: An Example From Civil Engineering. Computers \& Education. 49(3): 873-890.

Felicello, K. 2011. The iPod Touch as a Means for Providing English Language Arts Instruction in Grade Five. St. John's University (New York), School of Education and Human Services). ProQuest Dissertations and Theses, Retrieved from http://search.proquest.com/docview/1018548590?accountid=48462

Gunter, G. A., Kenny, R. F., \& Vick, E. H. 2006. A Case for a Formal Design Paradigm for Serious Games. The Journal of the International Digital Media and Arts Association. 93-105.

Hansel, T., Phimmavong, S., Phengsopha, K., Phompila, C., \& Homduangpachan, K. 2010. Developing and Implementing a Mobile Conservation Education Unit for Rural Primary School Children in Lao PDR. Applied Environmental Education and Communication. 9(2): 96103. Retrieved from http://search.proquest.com/docview/42859363?accountid=48462;http:// www.informaworld.com/openurl?genre=article\&id=doi:10.1080/15330 15X.2010.482475

Huizenga, J., Admiraal, W., Akkerman, S., \& Dam, G. t. 2009. Mobile Gamebased Learning in Secondary Education: Engagement, Motivation And
Learning In A Mobile City Game. Journal of Computer Assisted Learning. 25(4): 332-344. Retrieved http://search.proquest.com/docview/61876453? accountid=48462;http://dx.doi.org/10.1111/j.1365-729.2009.00316.x

Huang, W.-H., Huang, W.-Y., \& Tschopp, J. 2010. Sustaining Iterative Game Playing Processes in DGBL: The Relationship Between Motivational Processing and Outcome Processing. Computers \& Education. 55: $789 \mathrm{e} 797$.

Kinsey, J. 2011. Ten Family-friendly Apps for FCS Educators. Journal of Family and Consumer Sciences. 103(2): 57-58. Retrieved from http://search.proquest.com/docview/ 887105810 ?accountid $=48462$

Liaghatdar, M. J., Soltani, A., \& Abedi, A. 2011. A Validity Study of Attitudes Toward Science Scale Among Iranian Secondary School Students. International Education Studies. 4(4): 36-46.

Logan, M., \& Skamp, K. 2007. Engaging Students in Science Across the Primary Secondary Interface: Listening to the Students' Voice. Research in Science Education. 38(4): 501-527.

Mountain, L. A. 2009. Evidence Based Videoconferencing: Results of a Series Of Quasi-experimental Replication Studies. State University of New York at Albany). ProQuest Dissertations and Theses, Retrieved from http://search.proquest.com/docview/305093952? accountid=48462.

Payne, J. D. 2007. An Investigation of the Impact on Student Achievement of the Mobile Math Initiative in Three High Poverty Schools in a Single School District. The University of Alabama at Birmingham). ProQuest Dissertations and Theses, Retrieved from http://search.proquest.com/docview/ 304892458?accountid=48462.

Prensky, M. 2001. Digital Game-based Learning. New York: McGraw-Hill.

Rieber, L. P. 2005. Multimedia Learning in Games, Simulations, an Microworlds. In R. E. Mayer, The Cambridge Handbook of Multimedia Learning New York, United States of America: Cambridge University Press. 549-568.

Rubijesmin, A. 2007. Understanding Malaysian Students as Gamers: Experience . ACM DIMEA. 137-141.

Ruhaiza, R. (2012, May 21). Anggap Bidang Sains Tak Berbaloi. Retrieved from myMetro: http://www.hmetro.com.my/.

Sadiq, I. (2010, May). Effects of Online Games On Student Performance In.

Sadiq, I. 2010. Effects of Online Games on Student Performance in Undergraduate Physics. Proceedings of World Conference on Educational Multimedia, Hypermedia and Telecommunications. 36853691

San Chee, Y., Chwee Tan, K. D., Ming Tan, E., \& Fong Jan, M. 2009. Learning Chemistry with the game "Legends of Alkhimia": Pedagogical and Epistemic Bases of Design-for-Learning and the Challenges of Boundary Crossing. In K. Mijung, H. Sung Won, \& T. Aik-Ling (Ed.), Proceedings of International Science Education Conference 273-292.

Thang, S., Hanneghan, M., \& Rhalibi, A. E. 2009. Introduction to Game-based Learning. In T. Connoly, Game-based Learning Advancements for Multi-Sensory Human Computer Interfaces: Techniques and Effective Practices New York, United States of America: Information Science Reference. 1-17.

Varley, P. J., Murphy, C., \& Veale, Ó. (2011, October 22). At the Crossroads: The Impact of New Irish Science Curricula on First Year Post-Primary Students. Research in Science Education.

Wouters, P., Spek, E., \& Oostendorp, H. 2009. Current Practices in Serious Game Research: A Review from a Learning Outcomes Perspective. In T. Connolly, Game-based Learning Advancements for Multi-sensory Human Computer Interface: Techniques And Peffectives Practices. Information Science Reference. 232-249.

Yang, L. 2010. Toward a Deeper Understanding of Student Interest or Lack of Interest in Science. Journal of College Science Teaching. 39(4): 68-77.

Young, D. 2009. The History of Video Game-video Arcade Game Milestones. Retrieved July 6, 2011, from BMIgaming The World Largest Gaming Store: http://www.bmigaming. Com. 